\title{
1. Introduction: actorness and EU sanctions
}

[The notion of actorness] is an extraordinary creation that manages to combine a noun of dubious pedigree [i.e. 'actor'] with a suffix (-ness), which, elsewhere in the English language, is only applied to adjectives and participles, producing a result that is both quite impenetrable and slightly childish. (. . .) [I]t is used (. . .) in an attempt to express the concept of 'the quality of being an actor'. The association between this word and the EU is so strong that, at the time of writing, if we google say 'US actorness', we still get a list of entries concerning the EU. (European Court of Auditors, 2013: 11)

In 2013, the European Court of Auditors (ECA) published a paper named 'Misused English Words and Expressions in EU Publications' on its website. The author, a senior translator at the ECA's secretariat, deplores that '(. . .) the European institutions have developed a vocabulary that differs from that of any recognised form of English' (ibid.: 4). Among other things, the vocabulary '(. . .) includes words that do not exist or are relatively unknown to native English speakers outside the EU institutions (. . .)' (ibid.). The notion of actorness is one of the allegedly impenetrable words that is included in the paper. In defence of linguistic propriety, the author suggests replacing actorness with terms like 'active involvement' or 'participation'.

At the time of writing, the notion of actorness actually appears only once in a single document published in the Official Journal (OJ). The notion is referenced in inverted commas and is complemented by the words 'the concept of' (European Parliament, 2014: 34). Even the senior translator admits that actorness ' (. . .) is perhaps not actually an EU word as such, because it is not often found in EU publications themselves, it is used almost exclusively in publications about the EU' (European Court of Auditors, 2013: 11). To illustrate this claim, the paper cites Greiçevci's (2011) article 'EU Actorness in International Affairs: The Case of EULEX Mission in Kosovo'.

As Greiçevci's paper indicates, actorness is a scholarly concept referring to a complex and powerful idea. Cosgrove and Twitchett (1970: 12) originally introduced actorness to assess the degree to which international organisations acquire a 'capacity to act on the global scene'. The respective quality is by no means confined to the EU but might, in principle, be attributed to any other 
international organisation. The necessity to conceptualise international organisations as actors in their own right arose from the influence that the United Nations (UN) and the then European Economic Community (EEC) exerted on the international level.

The concept's originality lies in the idea that an international organisation might become more than an instrument of its (most powerful) member states. ${ }^{1}$ The affinity between actorness and the EU is thereby not surprising. The EU's outstanding institutional complexity and impact on the international system distinguishes it from any other international organisation and makes it a natural point of reference for research on the actorness of international organisations.

Ever since Cosgrove and Twitchett's initial attempt to conceptualise the quality of being an international actor, the construction of appropriate concepts to capture and scrutinise this very quality has become a much-debated issue. The essence of actorness was both cut down to its mere presence (Allen and Smith, 1990, 1998) and approached by multi-factor frameworks to conceptualise variable actorness across different policy areas (e.g. Bretherton and Vogler, 1999, 2006; Jupille and Caporaso, 1998), in part by designing highly complex models (Sjöstedt, 1977). Today, research on actorness is an extensive but highly fragmented field of scholarly interest.

In empirical research, some actorness concepts, or blends thereof, have been adopted to compare different international organisations either with each other (e.g. Hulse, 2014; Wunderlich, 2012), with states (e.g. Brattberg and Rhinard, 2013; Dandashly, 2016), or with both (e.g. Knutsen and Dønjar, 2016; Murau and Spandler, 2016). Another strand of research uses the concept of actorness to investigate the EU's foreign policy effectiveness in various policy areas (e.g. Boogaerts, 2018; da Conceição-Heldt, 2014; Delreux, 2014; Groen and Niemann, 2013; Thomas, 2012).

Although the notion of actorness is well established in contemporary research, it refers to a concept that is both remarkably fuzzy and under-theorised. Whilst most scholars would agree that actorness is by no means equivalent to 'active involvement' or 'participation', they would have a hard time agreeing on a commonly accepted definition. The major problem in the debate over actorness is that it is neither clear what the concept is supposed to describe precisely nor what it is supposed to explain. Even though most authors introduce their respective conceptual variant to examine a distinct phenomenon (for example impact, effectiveness or presence), no theoretical argument provides

1 Throughout this book, I use the notion 'member state' if I refer to the abstract quality of being a member of any international organisation. If I refer to the actions, interests and qualities of members of the EU, I will use 'Member States' in the capitalised variant. 
for a causal link between actorness and a dependent variable of whatever kind. Implicitly, there is a widely held conjecture that actorness, if only adequately conceptualised, is capable of providing an explanation for an international organisation's foreign policy output or outcome.

In comparative research, different international entities are frequently lumped together as if they were of the same category. Peters (2016: 2), for instance, naturally assumes that the EU, the United States (US) and the North Atlantic Treaty Organization (NATO) are all 'international actors'. Still, he wonders why "(. . .) hardly anyone is discussing the "power" or "actorness" of NATO or the US in the same vein as people (. . .) continuously seem to question the quality of the EU's "foreign policy" (ibid.). For Peters, as for others, it seems to be entirely out of the box thinking to assume that the three international entities are precisely not of the same nature, that is 'international actors' (see esp. ibid.: 19-24). Yet, comparing the actorness of international entities requires a sound understanding of what an actor is and whether this qualification applies to the EU, NATO and the US in the same vein. Otherwise, there is a high probability of comparing apples and oranges just to learn that both are fruits, but different.

This book addresses the conceptual and theoretical gap in the literature by presenting a deductive, integrative and explanatory model of actorness. The proposition put forward here is that actorness constitutes a distinct mode of collective agency that can be modelled along the lines of corporate action. The corporate action model of actorness builds upon Coleman's (1974a, 1990) work on corporate actors, established institutional theories and insights from European integration. Contrary to all competing conceptualisations, the corporate action model of actorness is thus based on solid theoretical ground. The model is integrative because it combines established strands of research in a coherent conceptual framework that covers both the activities of the member states and those of the international organisation's bureaucracy. Yet, the model draws a clear-cut distinction between the state of being an actor and the performance as an actor. Another useful feature of the model is that it allows for the distinction between collective state action and corporate organisational action-even if the decision-making process involves only states. Finally, the model is explanatory because it provides a reasonable explanation for when, how, why and to what degree international organisations might become actors in their own right.

To illustrate the explanatory power of the corporate action model of actorness, I explain the emergence of EU actorness in the field of international sanctions. At first glance, adding yet another empirical analysis to the rich field of EU actorness research seems to undermine any aspiration for generalisability. Yet, EU sanctions policies constitute an excellent test case for two reasons. 
First, restrictive measures (the official EU lingo for sanctions) constitute a least-likely case (see Eckstein, 1975: 108-23; George and Bennett, 2005: 120-23), because their imposition touches upon the core of national sovereignty. We do not generally expect states to cede foreign policy-making authority to international organisations. If the model is capable of explaining the emergence of actorness in an area of high politics, there is a high probability that the theorised mechanisms also work out for matters of low politics.

Second, whilst EU actorness is typically assumed in the field of international sanctions (e.g. de Vries and Hazelzet, 2005; Hellquist, 2012; Portela, 2010), many, albeit not all, restrictive measures are adopted unanimously by the Council. The case of EU sanctions policies thus reflects the traditional mode of decision-making in international organisations. But if the presence of intergovernmental procedures does not necessarily imply lack of actorness, which I argue, the concept's underlying argument similarly applies to other international organisations.

\section{THE THEORETICAL PUZZLE: WHO IS CALLING THE SHOTS?}

At the heart of the actorness debate lies a layered theoretical puzzle. For one thing, some scholars contend that the term 'actor' is rarely defined and that there is no consensus regarding the generic qualities which establish an international entity as an international actor (e.g. Drieskens, 2017: 1535; Sjöstedt, 1977: 5), or what 'to act' actually means (J. E. Oestreich, 2012: 11-15). Any effort to conceptualise international organisations as actors would thus be a highly idiosyncratic endeavour. For another, there is currently no cogent approach to conceptualising international organisations as separate actors. All established concepts of actorness are inductively compiled, tempting some scholars to value the concept's 'openness' (Murau and Spandler, 2016: 931). Conceptual openness is, however, a euphemism for the ambiguity and vagueness of empty conceptional containers. Open concepts establish umbrella terms with limited theoretical and empirical value (see esp. Sartori, 1984). The conceptual challenge is to provide a reasonable definition of actorness that is both in line with the general meaning of 'being an actor' and capable of describing precisely which instances are covered and which are not.

From an analytical point of view, the first layer of the theoretical puzzle is easy to solve. Whilst there is indeed no consensus on the precise characteristics that establish international actors, theory provides a sufficient answer. The simple truth is that international actors take many forms whose qualities and relevance become accessible only from a theoretical vantage point. Without embedding an actor in a compelling theoretical argument, the notion of 'actor' 
is rather a loose ascription invoking the metaphor of an international entity being somehow involved in things.

In the field of International Relations '(. . .) the term actor is used as a synonym for the units that constitute political systems on the largest scale. Actors, here, are akin to the players in a theatre-the dramatis personae' (Bretherton and Vogler, 2006: 15, original emphasis). Yet, the reality of an international sphere, or, to stay with the theatre metaphor, the international stage on which the actors perform, only exists against the backdrop of delimiting it from the state. International Relations is biased towards considering the state as the ontological starting point for theorising international politics. The discipline's very existence rests upon the idea of states being actors. Without the concept of 'the state', the concept of 'the international' could not be thought of. Unsurprisingly, many theories designed to study the international stage adopt a state-centric perspective.

However, the state is not, and never was, the only dramatis persona. Early, albeit implicit, challenges to the state-oriented ontology were advanced by scholars like Deutsch et al. (1957) and Haas (1958). Ever since the early 1970s, the exclusive emphasis on the state-as-actor perspective was explicitly put into question (e.g. Keohane and Nye, 1972; Young, 1972). Beside states, international organisations, non-governmental organisations, transnational corporations and even individuals were assumed to become actors in international politics. This led Young (1972: 139) to conclude that ' $(. .$.$) the shift$ toward a system of mixed actors has already reached a stage in which many new developments in the world system are difficult to explain satisfactorily in terms of orthodox assumptions and doctrines'. Whilst Young's argument is easily conceivable, the implications for conceptualising international organisations as actors in their own right are intricate.

The major problem for theorising mixed actor systems involving international organisations concerns the latter's relationship to the state. International organisations are typically founded by sovereign nation states to safeguard international cooperation. Therefore, traditional intergovernmental accounts consider international organisations the instruments of its founders (e.g. Keohane, 1984; Myrdal, 1955; Waltz, 2000). But a tool is merely a passive object, evolving its power only in the hands of the user. This argument leads to the second layer of the theoretical puzzle.

Conceptualising international organisations as separate actors requires transcending the state-centric perspectives without losing track of the state. The very idea of actorness is based on the assumption that an international organisation's capacity to act cannot be reduced to the interests, preferences and activities of its member states. Otherwise, intergovernmentalism would be the appropriate theoretical choice. Yet, a large part of what international organisations do is attributed to intergovernmental decision-making. Most of 
the established concepts of actorness simply ignore the member states' function in the institutional framework of international organisations. At times, the member states' role is even trivialised (e.g. Ellis, 2010). Delimiting actorness from collective state action thus becomes impossible.

Whereas intergovernmentalism explains many instances of what international organisations do, it is incapable of modelling their instrumental character. The reason why states back international regimes through international organisations is that the latter reduces the costs of cooperation through centralisation and delegation (Abbott and Snidal, 1998). A theoretical approach that covers this instrumental character is principal-agent theory.

Applied to international politics, principal-agent theory conceptualises international organisations as autonomous agents that perform specific functions (Hawkins et al., 2006a; Pollack, 1997). In a nutshell, principal-agent theory contends that states delegate certain authorities to organisational agents like boards, courts or secretariats. Although the employment of agents intends to facilitate cooperation, virtually every act of delegation comes at the expense of agency slacks - independent actions by organisational bodies because of a divergent interest between those who delegate authority and those to whom authority is delegated (Hawkins et al., 2006a: 7-10; Jensen and Meckling, 1976: 308-10). Since delegation typically furnishes an agent with a certain degree of autonomy and discretion, separate institutional interests might translate into independent action. In a way, this is even true when agents put the principal's will into practice through a one-on-one correspondence. Because discretion enables contingency of action, it is eventually up to the agent to decide matters in its province. In tangible terms, this means choosing one of several potential alternatives. Both the sovereigns of an international organisation and the outside world frequently conceive of an organisation's overall operation as acting on its own (Nielson and Tierney, 2003: 245). From an analytical point of view, the creation of agents associates new decision centres with the collectivity of principals, that is, the states.

Despite there being a reasonable understanding of how international bureaucracies might become autonomous actors who impinge on the activities of international organisations (e.g. Barnett and Finnemore, 2004; M. W. Bauer and Ege, 2016; Hawkins et al., 2006b), established concepts of actorness rarely incorporate an institutionalist perspective. The only concept that makes explicit reference to a rational institutionalist argument is that of Jupille and Caporaso (1998: 216). If anything, organisational agents are only considered part of an international organisation's capacity to act. The idea of actorness pretends to go beyond established institutional explanatory approaches by claiming to refer to an allegedly distinct phenomenon. Nevertheless, a compelling concept of actorness must account for both the agency of states and that 
of international agents. To date, none of the established concepts of actorness meets this criterion.

The reader may note that my perspective on the actorness problem is based on a combination of traditional intergovernmentalism and institutionalism. Whereas common approaches to the 'state of the art' typically rely on a combination of outlining the conceptual history and evaluating the various definitions of actorness (e.g. Drieskens, 2017; Koops, 2011: 95-146), I consider such an approach unrewarding in compiling an instructive synopsis. The problem is that the various conceptual strands of actorness research rarely speak to each other and merely describe different facets of the same thing. ${ }^{2}$ The actorness debate thereby bears a resemblance to Puchala's (1972) allegory of the elephant. Just replace 'international integration' with 'actorness' and you have a perfect summary of actorness's state of the art:

(...) [Y] ears of defining, redefining, refining, modeling and theorizing have failed to generate satisfactory conceptualizations of exactly what it is we are talking about when we refer to 'international integration' and exactly what it is we are trying to learn when we study this phenomenon. Part of the problem stems from the fact that different researchers have been looking at different parts, dimensions or manifestations of the phenomenon. Furthermore, different schools of researchers have exalted different parts of the integration 'elephant'. They have claimed either that their parts were in fact whole beasts, or that their parts were the most important ones, the others being of marginal interest. (Puchala, 1972: 267-8)

The starting point of this book is not a discussion of the various parts of the 'actorness elephant'. Instead, I adopt a traditional International Relations perspective to relate actorness to what we already know about actors and international organisations. Since intergovernmentalism and institutionalism are reliable tools to explain a whole lot of what international organisations do, actorness must build on these insights and expose what is not covered.

2 To illustrate the incommensurability of large parts of the actorness debate, the reader might consider the following juxtaposition. Kratochvíl et al. (2011) perceive actorness as a quality which affects, that is 'frames', the Member States' national discourses about EU foreign policy. Actorness is thereby understood as a combination of the elements legitimacy, attractiveness and recognition. To the contrary, Groenleer and van Schaik (2007) and Huigens and Niemann (2011) conceive of actorness what Sjöstedt (1977: 16) once described as the EU's '(. . .) capacity to behave actively and deliberately in relation to other actors in the international system'. Although the four authors refer to Sjöstedt's definition of actorness, they do not make use of his elaborate conceptualisation. Instead, they tacitly switch to Jupille and Caporaso's (1998) quadripartite definition of recognition, authority, autonomy and cohesion. As a result, actorness seems to constitute a 'term of conceptual convenience' (Drieskens, 2017: 1542). 
It is important to note that engaging in the actorness debate from a traditional International Relations perspective presupposes certain meta-theoretical assumptions about theory and actors that are not equally shared by all scholars working in the field. Yet, the debate on actorness is fragmented to such an extent that it is impossible to structure it productively without approaching it from firm theoretical ground. In philosophy, for instance, an alternative strand of research adopts a similar approach. Philosophers propose the 'supervenience' argument which aims at an explanation for how groups can have collective intentions (see List and Pettit, 2006, 2011; Pettit and Schweikard, 2006).

Against the backdrop of state agency and the agency of international bureaucracies, this book elaborates on the question of how and why international organisations become separate international actors. Hence, actorness is treated as a distinct phenomenon whose emergence is in need of explanation. Actorness must thereby not be confused or conflated with an international organisation's performance. To survey an international organisation's policy output, effectiveness or impact requires actorness to function as an independent variable. In this book, actorness is, however, considered the explanandum. Nevertheless, by providing counterfactual evidence for each empirical chapter, I suggest that the presence (or absence, respectively) of actorness can and does make a difference.

\section{THE CORPORATE ACTION APPROACH TO ACTORNESS}

The main proposition of this book is that actorness constitutes a distinct variant of corporate action. The corporate action approach to actorness is not yet another idiosyncratic interpretation of what actorness really is. Instead, the corporate action perspective establishes a productive dialogue between actorness and traditional theories of international organisations.

The idea of conceptualising actorness in terms of corporate action is not a new one. Kenis and Schneider (1987) were the first to realise a corresponding approach, but it has long been unappreciated. Most established concepts of actorness simply ignore the instructive literature on corporate actors, except for one honourable mention (Jupille and Caporaso, 1998: 217). Only recently, Gehring et al. (2013) and Gehring et al. (2017) readopted and advanced the corporate action perspective in the debate on EU external actorness. The conceptual reference point for all these authors are Coleman's (1974a, 1990) seminal works on corporate actors.

Unfortunately, a straightforward application of Coleman's corporate action perspective to international organisations is impossible. Two difficulties have hitherto prevented uniform adoption of the corporate action perspective for the conceptualisation of actorness. 
First, Coleman's work on corporate actors is primarily driven by a desire to understand the structure and behaviour of complex social systems. Though corporate actors are an essential part of modern society, Coleman has never provided a concise definition of what a corporate actor ultimately is. Thus, depending on their focus, different researchers draw on different aspects of the corporate action perspective.

Second, international organisations are not corporate actors per se but may also '(. . .) provide meeting places for members to come together to discuss, argue, co-operate or disagree' (Archer, 2001: 73). Involvement of international organisations thus indicates passive presence of an institutionalised arena in which actors (that is, states) make choices. The conceptual shift from arena to actorness entails a metabasis eis allo genos which is underspecified in all conceptualisations seeking to apply Coleman's corporate action perspective to the EU. For instance, Gehring et al. (2013: 850) point to the fact that actorness is different from collective member state action. Nevertheless, they base their adoption of the corporate action perspective on a diffuse combination of the two variables autonomy in goal formation and control over governance resources. Whilst the proposed argument certainly explains why the EU is recognised as an actor in some international institutions but not in others, the conceptual limits of actorness remain rather fuzzy.

To cope with these problems, I model actorness based on what Vanberg (1978: 271) once labelled Coleman's 'combining resource model'. The argument for why and how international organisations might become separate international actors is developed in Chapter 2 and comprises four steps.

First, the model is based on a utilitarian point of view. States and agents are conceptualised as rational utility maximisers whose choices are subject to information asymmetries and other limitations. Though agents are essentially capable of autonomous action, the relationship between states and agents is strictly hierarchical. The status of states as sovereign entities is key in understanding international affairs. If a delegation relationship is detrimental to a principal on a permanent basis, states are expected to either seek institutional adaption or to withdraw from the respective organisation.

In a second step, I adopt a rational institutionalist argument to explain why states establish international organisations in the first place. Modern international politics is shaped by complex interdependencies between policy areas, regions and states. To secure welfare gains in such interdependent settings, states have strong incentives to institutionalise mutual cooperative behaviour (Keohane, 1984: 65-84). Whenever the benefits of cooperation outweigh the costs, states are expected to establish and maintain international regimes. Some international regimes are safeguarded by international organisations. International organisations fulfil specific functions closely related to the nature of the cooperation's underlying interdependencies and the preference config- 
uration of the participating states (Abbott and Snidal, 1998, 2000; Koremenos et al., 2001).

In a third step, I establish the corporate action model of actorness in relation to the functional dimension of international organisations. Many functions, for instance, securing credible commitment, producing neutral information or agenda-setting, require that the member states vest the international organisation with respective capabilities. If such an investment of capabilities, or 'resources', implies that the investors yield control over their share of the investment to a 'common pool' (that is an international organisation), a corporate actor comes into existence (see esp. Vanberg, 1978). The common pool is governed by jointly agreed upon decision-making procedures and units divesting it from the sovereign control of individual member states. I identify four generic types of corporate institutions that employ pooled resources: (1) consensus among the participating states, (2) voting procedures, (3) delegation to an agent and (4) through collaboration between agent and states.

The corporate action model of actorness establishes a sharp distinction between corporate and collective actors. What distinguishes these two types of actors is the utilisation of different types of resources. The activities of a corporate actor rely upon common pool resources whereas the activities of collective actors rely on the joint use of privately held resources. Accordingly, the members of a corporate actor continue to pursue their own interests and goals, but their very membership restricts the ways in which these can be articulated or realised (Kenis and Schneider, 1987: 441). Actorness is, however, not a holistic quality. The more stages of the policy cycle draw on common pool resources, the more actorness an international organisation acquires. Decision-making and policy implementation are arguably the most important capabilities in this regard.

In a last step, I identify two mechanisms that explain the emergence of actorness in a distinct policy area. The two mechanisms offer competing explanations and any instance of actorness traces back to either one of them.

The first mechanism relies on intergovernmental authorisation which is typically considered the default in the creation of international organisations. The emergence and scope of actorness depend on a group of states' deliberate and expressed will to pool certain governance resources under corporate control. To promote international cooperation, pooled resources are functionally tied to the requirements of the underlying regime. As a result, the first mechanism considers the emergence of actorness as being intentionally built into an international organisation's institutional structure.

The second mechanism involves what I call a sovereignty pooling induced spill-over. With increasing institutional complexity, functional links between pooled resources and national prerogatives might expand the scope of actorness to new policy areas. Whenever states try to pursue separate foreign 
policy goals that require employment of previously pooled resources, there is a high probability that the authority to govern respective areas also shifts to the international level. Since states have previously given up control over their share of resources, separate national pursuance of the policy in question would jeopardise the original cooperation project. A similar effect occurs if organisational agents employ pooled resources for non-approved goals. If the member states cannot retrieve alienated resources without putting the original cooperation project at risk, they have to accept the expansion of actorness. In both cases, the emergence of actorness results from a spill-over effect rather than from deliberate intergovernmental authorisation.

\section{EU ACTORNESS IN THE FIELD OF INTERNATIONAL SANCTIONS}

To illustrate the viability of the corporate action model of actorness, I apply it to the realm of European sanctions policies. Whilst the choice of European sanctions as a 'test case' for the model is primarily driven by methodical considerations, the test itself sheds light on two blind spots in the research on, and the understanding of, the EU as a separate actor in the field of international sanctions. By way of example, I demonstrate the utility of the actorness model by closing a gap in the literature on EU restrictive measures.

\section{Two Blind Spots in the Literature on EU Sanctions Policies}

The first blind spot in the literature concerns the question whether and to what extent the EU constitutes a separate actor in the field of international sanctions. Whilst the EU is typically considered an actor per se, there is no consensus among scholars of when European sanctions regimes have turned into a corporate EU policy. In addition, established scholarship struggles with the ostensibly simple question of identifying the correct number of past European sanctions regimes.

Just a few examples illustrate this. De Vries and Hazelzet (2005: 98) state, for instance, that '[b]efore 1990 it was the Member States of the EU that took, individually or collectively, sanctions against certain countries without a prior UN Security Council decision'. Consequently, it makes sense that Buchet de Neuilly (2003: 92) considers the measures against Serbia in 1998 the EU's first autonomous sanctions. ${ }^{3}$ Yet, Portela $(2010: 20)$ considers the measures

3 The literature on EU sanctions policies refers to 'autonomous' measures if 'the EU' imposes restrictive measures which have not been mandated by the UN Security Council. 
against the Soviet Union in 1980 the first instance of autonomous EU sanctions, whereas Kreutz's (2005: 17) list of EU sanctions policies begins with measures against the Soviet Union only in 1982. In contrast, Jones (2007: 107) finds that '(. . .) between 1950 and 1990 European states sanctioned through the European Community only twice out of seventeen cases'. Interestingly, Jones's list does not at all include the two cases against the Soviet Union which have been identified by Kreutz and Portela.

Another example concerns the number of EU arms embargoes. The Stockholm International Peace Research Institute's (SIPRI) database on arms embargoes shows that the EU has imposed 38 arms embargoes since 1986 (SIPRI, 2019). SIPRI's arbitrary choice of the year 1986 as the starting point for the historical record of EU arms embargoes found its way into research on the subject (Kranz, 2016: 971). Yet, SIPRI's database does not consider the arms trade ban against Argentina in 1982 (European Commission, 1982a: 7) or the arms export restrictions against the Soviet bloc which have been implemented by the Member States in line with the provisions of the Coordination Committee for East West Trade Policy (Kuijper, 1992: 69-75).

The second blind spot concerns the explanation for the emergence of EU actorness in the field of international sanctions. There is currently no theoretically informed explanation for why European sanctions have been progressively channelled through the complex institutional structure of the EU.

Scholarly interest in EU sanctions policies is primarily driven by other objectives. For instance, descriptive accounts of one or several cases provide a general overview of sanctions episodes in which the EU and its institutional precursors were involved (e.g. de Vries and Hazelzet, 2005; Eriksson, 2005; Holland, 1991). Law scholars investigate the legal aspects of EU restrictive measures (e.g. Cameron, 2013a; Eikenberg, 2000; Weidel, 2002). Another strand of literature is dedicated to the design, effectiveness and impact of EU restrictive measures (e.g. de Vries et al., 2014; Giumelli, 2013; Portela, 2010).

Only Jones (2007) has tentatively addressed the question of why Member States have increasingly imposed sanctions through the EU. For Jones, EU sanctions are a manifestation of a broader strategy primarily driven by European great powers to enhance Europe's global power. Still, this explains neither why collaboration was institutionalised within the framework of the EU, nor why different types of sanctions are governed by distinct types of decision-making procedures. It is not just that the costs of restrictive measures are unevenly distributed among Member States; sanctions might also involve redistributive effects (Giumelli, 2017). Hence, the Member States would have been much better off if they had relied on intergovernmental coordination of national measures. My analysis shows that this is indeed how the first European sanctions regimes came into existence. 
The corporate action model of actorness is capable of providing a reasonable explanation for the EU's development as a separate actor in the field of international sanctions. The conceptual framework allows for a clear-cut distinction between collective Member State measures and corporate EU measures. The empirical analysis discloses the turning points in which some restrictive measures became a separate EU policy. By testing two competing hypotheses about the emergence of actorness, I ascertain whether EU actorness resulted from intergovernmental authorisation $\left(H_{1}\right)$ or from a sovereignty pooling induced spill-over $\left(H_{2}\right)$. By tracing the emergence of actorness with a focus on resources and institutions of corporate governance, I explain why different types of sanctions are adopted by different types of procedures. Although the research focus of this book is not on compiling past cases of EU restrictive measures, the actorness model may help to structure future research on the development of collective European and corporate EU sanctions policies.

\section{Eight Case Studies in European Sanctions Policies}

Two research enquiries guide the empirical investigation. On the one hand, the analysis determines whether and to what degree the EU constitutes a separate actor in the field of international sanctions. On the other, if the analysis confirms EU actorness, its emergence is in need of explanation. Since the pooling of resources under corporate control is key to understanding the emergence of actorness, it is similarly constitutive for identifying the cases for the empirical analysis.

A case study is ' (. . .) an intensive study of a single unit for the purpose of understanding a larger class of (similar) units. A unit connotes a spatially bounded phenomenon (. . .) observed at a single point in time or over some delimited period of time' (Gerring, 2004: 342). In this book, the phenomenon under study is the emergence of actorness. Consequently, EU actorness in the field of international sanctions is an instance of an international organisation's actorness in a distinct policy area.

To avoid confusion of what exactly constitutes 'a case', a few words of clarification are in order. The literature on European sanctions typically considers sanctions, or a series of sanctions, against a specific target 'a case'. In this enquiry, a case is, however, the EU's potential for agency based on a joint and authoritative use of pooled resources by institutions of corporate governance. Therefore, each 'type of sanction' constitutes a separate case.

The framing of the universe of cases is substantiated by three compelling arguments.

First, different types of sanctions require different types of resources. The employment of these resources is channelled through varying institutions. Consequently, the authority to impose restrictive measures cannot be treated as 
a unified competence. The EU may possess actorness regarding one sanction instrument whereas it lacks actorness regarding another.

Second, according to the principle of conferral the EU acquires only those resources which have been deliberately and voluntarily conferred to it (van Vooren and Wessel, 2014: 74-6). The principle of conferral is equivalent to hypothesis $H_{1}$ and generally allows for contingency in the emergence of actorness regarding different sanction instruments.

Third, the literature identifies a 'multi-pillar' (Buchet de Neuilly, 2003) or 'cross-pillar' (Stetter, 2004) dimension of European foreign policy. European integration thus predisposes corporate governance in one policy area to spill over to another $\left(\mathrm{H}_{2}\right)$. But if different types of sanctions rely on different types of resources, a spill-over may certainly not affect all instruments in the same way. As a result, European sanctions policies constitute a sub-population of the actorness phenomenon. Individual types of sanctions in turn constitute single cases.

An early version of the EU's 'Guidelines on Implementation and Evaluation of Restrictive Measures' divides European sanctions into four broad categories: (1) arms embargoes, (2) import and export restrictions, (3) visa or travel bans and (4) financial restrictions (Council of the European Union, 2003). In addition to this, the literature on European sanctions identifies other types of measures, namely diplomatic sanctions, suspension of cooperation with third countries and flight bans (Gazzini and Herlin-Karnell, 2011; Kreutz, 2005; Portela, 2010). Because these categories are not mutually exclusive, they complicate case selection. Arms embargoes are at the same time export restrictions whereas suspension of cooperation with third countries may also involve financial restrictions.

Since there is no proper way to solve the problem of overlapping sanctions categories, case selection is guided by three considerations.

First, the purpose of focusing on European sanctions policies is to illustrate the explanatory power of the corporate action model of actorness. Hence, it makes sense to focus on the most prominent types of measures. These measures are enumerated in the EU's 'Guidelines on Implementation and Evaluation of Restrictive Measures'.

Second, restrictive measures are adopted by reference to different legal frameworks. This suggests that there have been different paths to potential EU actorness. Portela (2010: 49) considers four such legal bases: (1) the Common Foreign and Security Policy (CFSP), (2) the Partnership Agreement between the European Union and the group of African, Caribbean and Pacific countries (ACP), (3) the Generalised Scheme of Preferences (GSP) and (4) 'informal sanctions'.

Third, restrictive measures generally aim at three different types of targets: countries, companies and (groups of) individuals. The difference between 
countries, on the one hand, and companies and individuals, on the other hand, is that states can be targeted by reprisals and retorsion (White and Abass, 2010: 537-8). In contrast, companies and individuals enjoy legal protection if measures directed against them are not legally justified (Arts. 75 and 215, Para. 3 of the Treaty on the Functioning of the European Union (TFEU)).

To cover these considerations, I cluster eight sanction instruments into four broad categories. These four categories inform the structure of the empirical part of this book.

The first two case studies (Chapter 3) scrutinise whether the EU is a separate actor in the field of trade restrictions. The related instruments are boycotts and embargoes. Trade restrictions target third countries and are adopted intergovernmentally within the framework of the CFSP. The implementation of trade restrictions is, however, subject to a Council decision adopted by a qualified majority. This combination of intergovernmental and supranational procedures is codified in Article 215 TFEU. The fact that trade restrictions are governed by a distinct treaty provision seems to support the intergovernmental authorisation hypothesis $\left(H_{1}\right)$. Yet, with the ever-increasing economic integration in Europe, national pursuance of trade restrictions becomes a tricky issue. Governance of trade-related measures generally falls under the supranational authority of the Community's Common Commercial Policy (CCP). Any separate national import or export ban would open various loopholes for target countries to avoid harm. To fix these loopholes, the Member States '(. . .) would have to reinstate customs procedures and control of payments, i.e. seriously to impair the functioning of the Common Market' (Kuyper, 1975: 235). Consequently, the functional link between trade restrictions and the communitarised competence of governing the Internal Market might have also allowed for a sovereignty pool induced spill-over $\left(H_{2}\right)$.

Case studies three and four (Chapter 4 ) explore the potential emergence of EU actorness regarding arms embargoes and sales bans on dual-use technology. Respective measures typically target states but may also be directed at terrorist organisations like, for instance, al-Qaeda. Unlike ordinary commercial goods, trade in arms and dual-use commodities is much more responsive to the security considerations of individual Member States. Unsurprisingly, Article 346 Paragraph 1(b) TFEU emphasises that ' (. . .) the production of or trade in arms, ammunition and war material (...)' is excluded from the CCP. Since the export of arms and dual-use technology is generally subject to national licensing procedures, restrictive measures are not adopted in line with Article 215 TFEU. Hence, there is tentative evidence that strategic embargoes constitute a negative case of EU actorness. Yet, the exemption of Article 346 TFEU does not apply to arms and dual-use products in the same way. The export, transfer, brokering and transit of dual-use items is governed by a Council Regulation that is explicitly based on the communitarised CCP. Due to the civil use of 
dual-use products, export restrictions on these commodities are located at the interface of national security, the CFSP and the CCP. Dual-use items thus occupy a special position that is neither equivalent to that of commercial goods nor to that of arms. The analysis will show whether European dual-use sanctions result from collective Member State action or from corporate EU action. By tracking the differences between arms, dual-use items and commercial goods, I explain the different modes of governing strategic embargoes.

Case studies five and six (Chapter 5) focus on travel bans and asset freezes. Both types of sanctions are targeted, or 'smart', measures tailored to inflict harm on individuals, groups or economic sectors that are specifically linked to them (Brzoska, 2015: 1340). Individuals targeted by a travel ban will be denied entry to, or transit through, the EU. Asset freezes concern financial assets and other economic resources belonging to targeted companies or individuals. The legal basis for these two sanction instruments is typically an intergovernmental CFSP Council decision. Targeting the financial assets of terrorists might also be subject to the ordinary legislative procedure. Decisions on travel bans are directly binding whereas the implementation of asset freezes is a separate supranational authority (Arts. 75 and 215 TFEU). Due to their allegedly exclusive intergovernmental character, imposition of travel bans seems to be a negative case for EU actorness. To the contrary, supranational implementation of asset freezes in line with specific treaty provisions suggests previous intergovernmental authorisation $\left(H_{1}\right)$.

A distinctive feature of targeted sanctions is that the affected target's due process rights are comprehensively protected. As a result, the European Court of Justice (ECJ) did not only become a court of appeal for targets of European sanctions but has also adjudicated on measures aimed at individuals listed on the UN Security Council's counterterrorist list. In 2008, the ECJ found in the so-called Kadi case that certain Security Council measures may not be implemented by the EU if they violate fundamental rights that are part of the very foundations of the European legal order (Court of Justice, 2008). Whilst the EU is traditionally recognised as a 'regional interface' (Bethlehem, 2001) authorised to process Security Council decisions for the Member States, the ECJ has never been authorised to review the legality of UN sanctions. In fact, this practice undermines the Security Council's primary responsibility for maintaining international peace and security (Art. 24 UN Charter). Hence, the EU's authority to de facto suspend UN sanctions if they violate due process rights is the likely result of a spill-over from the EU's entrenchment of the rule of law $\left(\mathrm{H}_{2}\right)$.

The last two case studies (Chapter 6) scrutinise whether the EU became a separate actor in the field of negative conditionality. The related instruments are the suspension of development cooperation under the Partnership Agreement and the withdrawal of GSP benefits. Both instruments are designed 
to help underdeveloped countries to fight poverty and to integrate their national markets into the world economy. Yet, financial assistance under the Partnership Agreement and preferential market access under the GSP are conditioned on compliance with standards of good governance and respect for human rights. If a beneficiary fails to comply with these standards, the EU may reduce or terminate cooperation. Because of the functional link between the granting of preferential market access under the GSP and the communitarised governance of the CCP, there is a high probability that the EU acquired actorness in this field. Both intergovernmental authorisation $\left(H_{1}\right)$ and the sovereignty pooling induced spill-over $\left(\mathrm{H}_{2}\right)$ may have accounted for the emergence of actorness. The suspension of development cooperation under the Partnership Agreement seems to constitute a unique case of EU actorness. Contrary to all other forms of European sanctions, the suspension of development cooperation is based on a contract between the EU, the Member States and the ACP countries. The Partnership Agreement defines the conditions and procedures for a suspension and explicitly establishes the EU as the ACP countries' counterpart on the international level. The joint conclusion of the Partnership Agreement hints at a formal empowerment through intergovernmental authorisation $\left(H_{1}\right)$.

\section{SUMMARY AND ORGANISATION OF THE BOOK}

The central argument of this book is that actorness establishes international organisations as separate international actors whenever states pool formerly nationally held resources under corporate control. The more stages of the policy cycle that are based on common pool resources, the more actorness an international organisation acquires. Hence, not every involvement of an international organisation indicates actorness. If states coordinate the collective employment of national resources, international organisations merely function as institutionalised arenas that facilitate cooperation. Accordingly, the EU's degree of actorness varies considerably across different types of sanctions and different stages of the policy cycle.

The analysis finds that EU actorness is most developed regarding trade restrictions and instruments of negative conditionality. It is least developed regarding strategic embargoes and travel bans. In any case, actorness traces back to either one of two mechanisms. If actorness was deliberately built into the organisational structure, it is the result of intergovernmental authorisation. If actorness is the result of an uncalculated spill-over from functionally interlocked policy areas, it traces back to a sovereignty pooling induced spill-over.

To substantiate these arguments, this book proceeds in three parts: Chapter 2 develops an original model of actorness based on the idea of corporate action. To explain the emergence of actorness, I identify two competing mechanisms. The first mechanism relies on a joint and deliberate decision to pool national 
authorities and resources under corporate control. The second mechanism plays on functional links between the common pool and national prerogatives.

To illustrate the usefulness of the corporate action model of actorness and to test whether the two mechanisms work as theorised, I apply the model to the field of European sanctions. I conduct eight case studies each representing a distinct sanction instrument. The eight sanction instruments are clustered into four broad categories which inform the structure of the empirical part of this book. Chapter 3 scrutinises whether the EU is a separate actor in the field of trade restrictions. The related sanction instruments are boycotts and embargoes. Chapter 4 explores the potential emergence of EU actorness regarding arms embargoes and sales bans on dual-use products. The respective category is referred to as strategic embargoes. Chapter 5 focuses on travel bans and asset freezes as two representatives of the category of targeted sanctions. Chapter 6 scrutinises whether the EU became a separate actor in the field of negative conditionality. The related instruments are the suspension of development cooperation under the Partnership Agreement and the withdrawal of GSP benefits.

In a last step, Chapter 7 summarises the findings of the investigation, outlines the contribution to research and discusses the theoretical and practical implications and limitations of the corporate action model of actorness. Although the actorness model establishes a sharp distinction between the state of being an actor and the performance as an actor, the empirical investigation produces tentative insights into how these two dimensions interact. This actorness-performance nexus is also discussed in the final chapter. 